\title{
Multi-Parameter On-Line Coal Bulk Analysis
}

\author{
Quarterly Report \\ March 16 - June 15, 1997 \\ By: \\ George Vourvopoulos

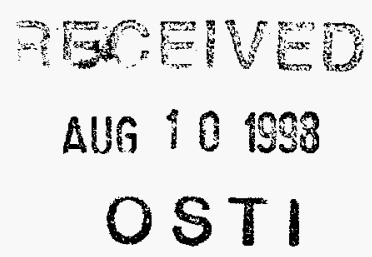

Work Performed Under Contract No.: DE-FG22-93PC93211

For

U.S. Department of Energy

Office of Fossil Energy

Federal Energy Technology Center

P.O. Box 880

Morgantown, West Virginia 26507-0880

By

Western Kentucky University

1526 Russellville Road

Bowling Green, Kentucky 42101

DSTMBUTON OF TH: DOCUMENT IS UNLMMTED 


\section{Disclaimer}

This report was prepared as an account of work sponsored by an agency of the United States Government. Neither the United State Government nor any agency thereof, nor any of their employees, makes any warranty, express or implied, or assumes any legal liabilit or responsibility for the accuracy, completeness, or usefulness of an information, apparatus, product, or process disclosed, or represents that its use would not infringe privately owned rights. Reference herein to any specific commercial product, process, or service by trade name, trademark, manufacturer, or otherwise does not necessarily constitute or imply its endorsement, recommendation, or favoring by the United States Government or any agency thereof. The views and opinions of authors expressed herein do not necessarily state or reflec those of the United States Government or any agency thereof. 


\section{DISCLAIMER}

Portions of this document may be illegible in electronic image products. Images are produced from the best available original document. 


\title{
TECHNICAL PROGRESS REPORT
}

\section{3/16/97-6/15/97 PERIOD}

\author{
GRANT DE-FG22-93PC93211- - 15 \\ MULTI-PARAMETER ON-LINE COAL BULK ANALYSIS
}

\section{Personnel}

A meeting was held on April 3 with personnel from the French company SODERN which specializes in the manufacturing of neutron generators and associated nuclear electronics, and personnel from the company John B. Long that specializes in coal sampling equipment. Purpose of the meeting was to lay the foundation for a cooperation that will lead to the development of a prototype on-line coal analyzer. This was followed by a visit to France (June 23) at the company's headquarters, were the formal cooperation documents were discussed and the SODERN nuclear electronics that will become part of the prototype were decided.

Personnel from the Applied Physics Institute attended the "Kentucky Commercialization \& Entrepreneurship Institute" in Harrodsburg, KY April 21-23.

A paper entitled "Calculations of Neutron Transport Through a Simulated Waste Matrix" Womble, Vourvopoulos, Ball and Persons, was accepted for publication at the journal Nuclear Instruments and Methods.

The papers entitled "Pulsed Fast and Thermal Neutron Analysis for Coal and Cement Industries" Dep and Vourvopoulos, and "An Application of the RFQ Linac: Nuclear Waste Assay \& Characterization" Lamkin, Schultz, Womble, Humphrey and Vourvopoulos were published in CP-392, AIP Press, 1997.

A report of the research highlights was prepared for the annual University Coal Research Contractors Review Meeting, June 3-4.

\section{Scientific work}

\section{Measurement layout}

Preparations were initiated for the layout of the coal sampling system and the detector setup to be used for the prototype on-line coal analyzer. Based on the previous experimental work and extensive MCNP calculations, a preliminary sketch of the layout is shown in Fig. 1. There are two coal chutes : the main one $(M)$ with a $40 \mathrm{~cm}$ diameter through which coal flows continuously at a rate of 3-5 tons $/ \mathrm{hr}$, and the auxiliary one $(X)$ with $25 \mathrm{~cm}$ diameter 
where coal flows in $8 \mathrm{~kg}$ batches every $30-40$ seconds. The neutron generator $(A)$ is located between the two chutes, and fires continuously $14 \mu \mathrm{s}$ wide neutron pulses with 14 $\mathrm{kHz}$ frequency. Gamma-ray detectors (B) are located around the main chute for the measurement of gamma-rays from fast and thermal neutron induced reactions. The auxiliary chute is used for neutron activation measurements. An $8 \mathrm{~kg}$ coal sample is accumulated at position $(C)$ and is bombarded for a preset time (30-40 s) with neutrons from the neutron generator $(A)$. At the end of the bombardment period, the sample is transferred within $2 \mathrm{~s}$ to a lower position approximately $2 \mathrm{~m}$ away from the neutron generator. At that position, a gamma-ray detector $(D)$ measures the gamma-rays from activation analysis.

\section{Detector temperature stabilization}

The BGO detectors used in the system are sensitive to changes of ambient temperature. The light collection efficiency is temperature dependent, and this results to gamma-ray pulse height drifts. Although the data acquisition system contains a stabilization system, whereby any detected pulse height drift is compensated by the appropriate change in the zero offset and slope of the calibration line, it was decided to minimize the burden on the software stabilization and temperature stabilize each BGO detector with thermoelectric cooling. Figure 2 shows the temperature stabilization and thermal neutron shielding for each detector. The bare BGO crystal is surrounded by a $2.5 \mathrm{~cm}$ thick boron nitride jacket used as thermal neutron shielding. Surrounding the boron nitride shield is an Al shell onto which the thermoelectric coolers are attached. The coolers are to maintain the detectors at a constant temperature of $12^{\circ} \mathrm{C}$. The system was designed by us and was sent to a company for machining.

\section{Raw coal library}

In order to create a coal library to be used for the calibration of each major and minor chemical element in coal, eighteen 55 gallon coal drums (approximately $190 \mathrm{~kg}$ each) were procured from various coal mines and coal preparation plants in eastern United States and Canada. Several drums with coal from Wyoming and Utah coal mines have also been secured and will be soon arriving at the Applied Physics Institute. A special coal preparation facility was established at the Institute to handle these coal samples. The contents of each barrel were air dried then split. From the splits, a $60 \mathrm{~kg}$ sample was placed in a sealed $45 \mathrm{~cm}$ diameter fiber drum and was used for the on-line analysis. Another smaller mass sample was used for the ASTM proximate and ultimate laboratory analysis.

\section{Determination of BTU content from elemental concentrations}

An important coal bulk parameter is the BTU content. A premise for the current research is the correlation between elemental concentration and BTU content in coal as shown in 
earlier work by several authors (e.g. R.C. Neavel et al, FUEL 65 (1986)). To examine in a greater detail this correlation, 450 coal samples were picked from the USGS coal library, for which a complete elemental analysis exists and several bulk properties including BTU content have been measured. Figure 3 shows a comparison between measured BTU content and calculated BTU content through an equation that contains $\mathrm{C}, \mathrm{H}, \mathrm{O}, \mathrm{S}$, and ash. The coefficients in the equation were established through a regression analysis. The figure shows that the measured and calculated BTU contents differ by less than 50 BTU/lb over a wide range of BTU values.

This work is currently extended to establish whether the BTU content can be established without including the ash content, for the low ash coals. Furthermore, the USGS coal data base is currently utilized to establish the correlation between ash measured with ASTM methodology and ash determined through the measurement of the elemental content. 


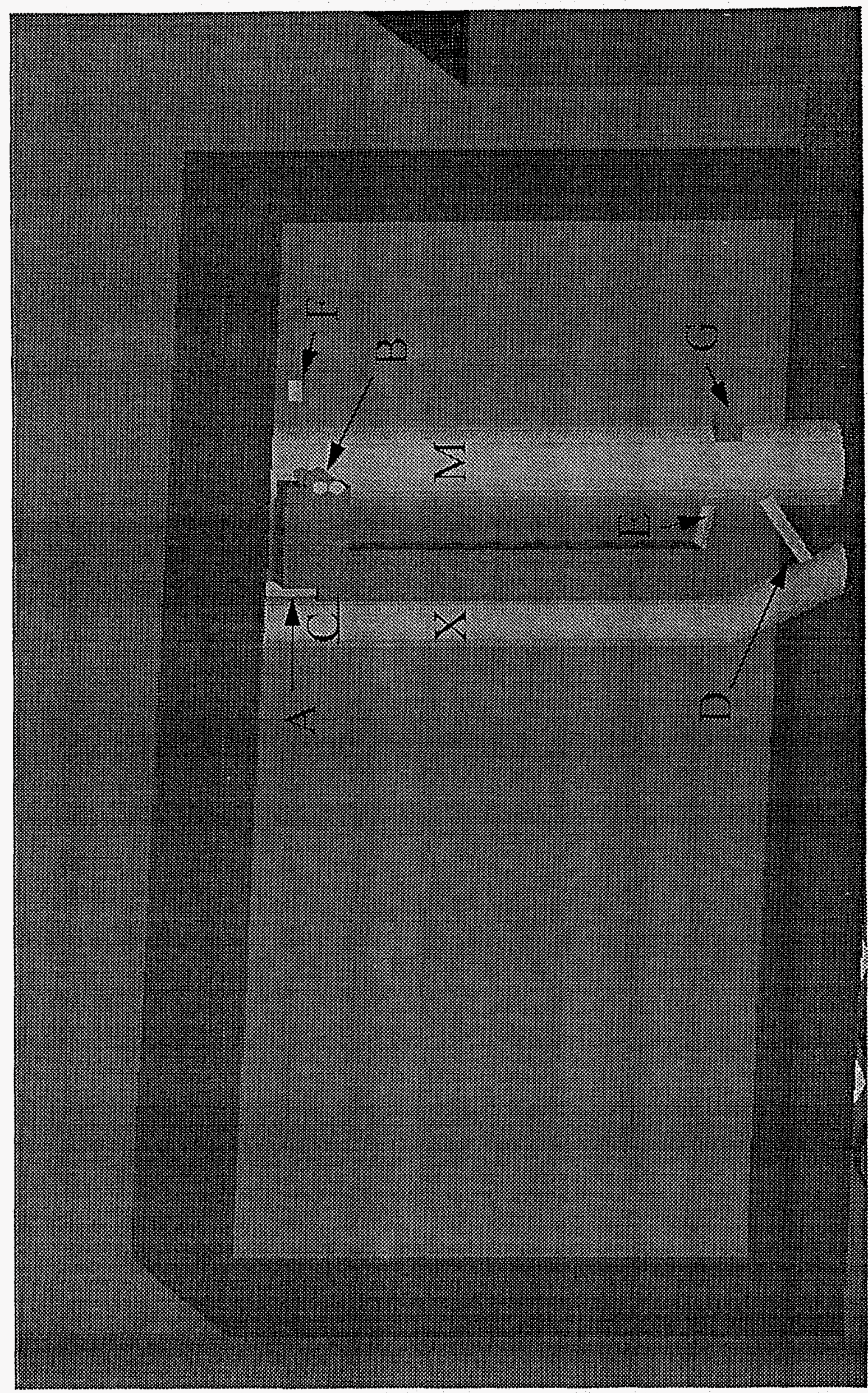




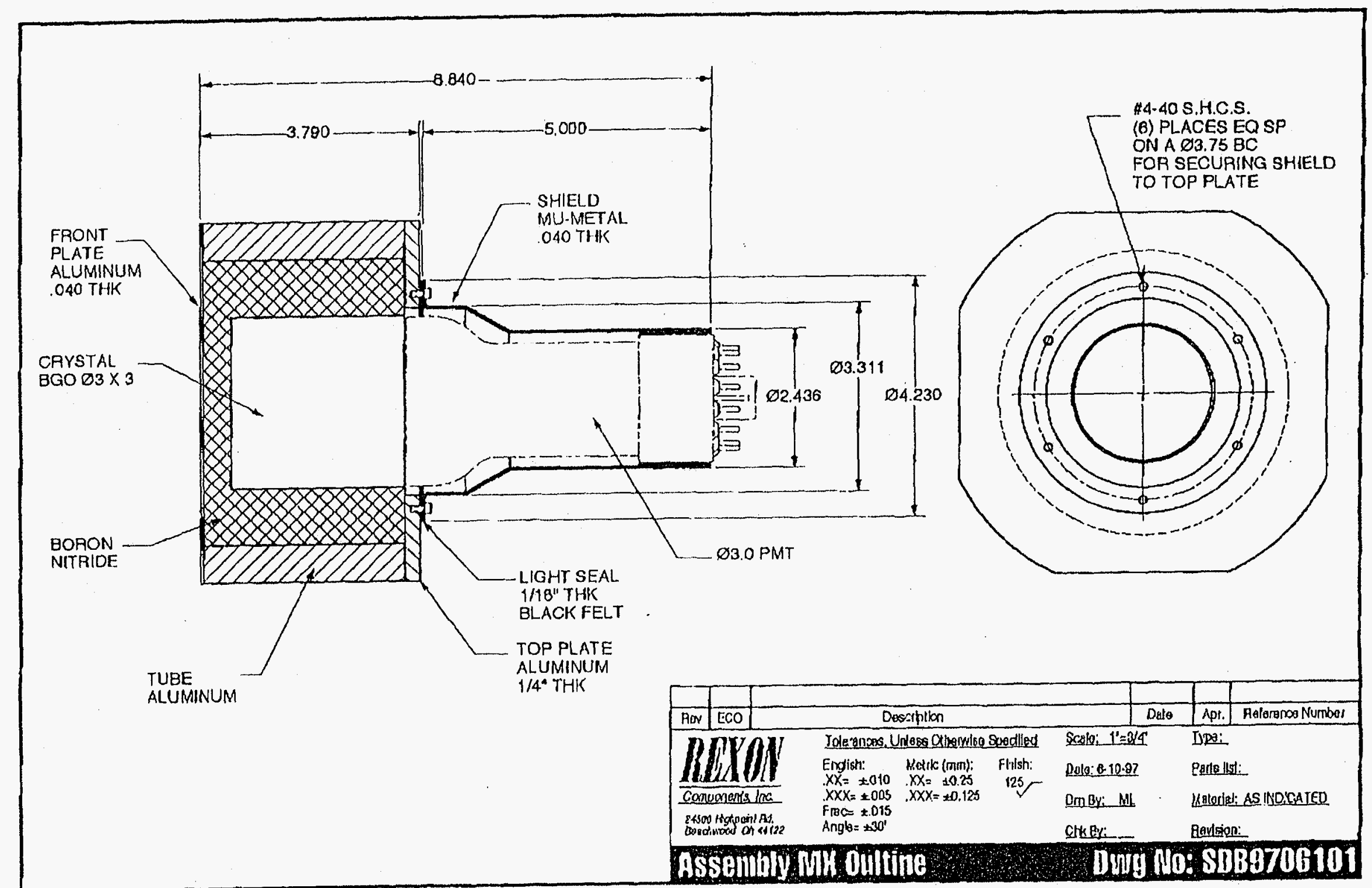

Figure 2 


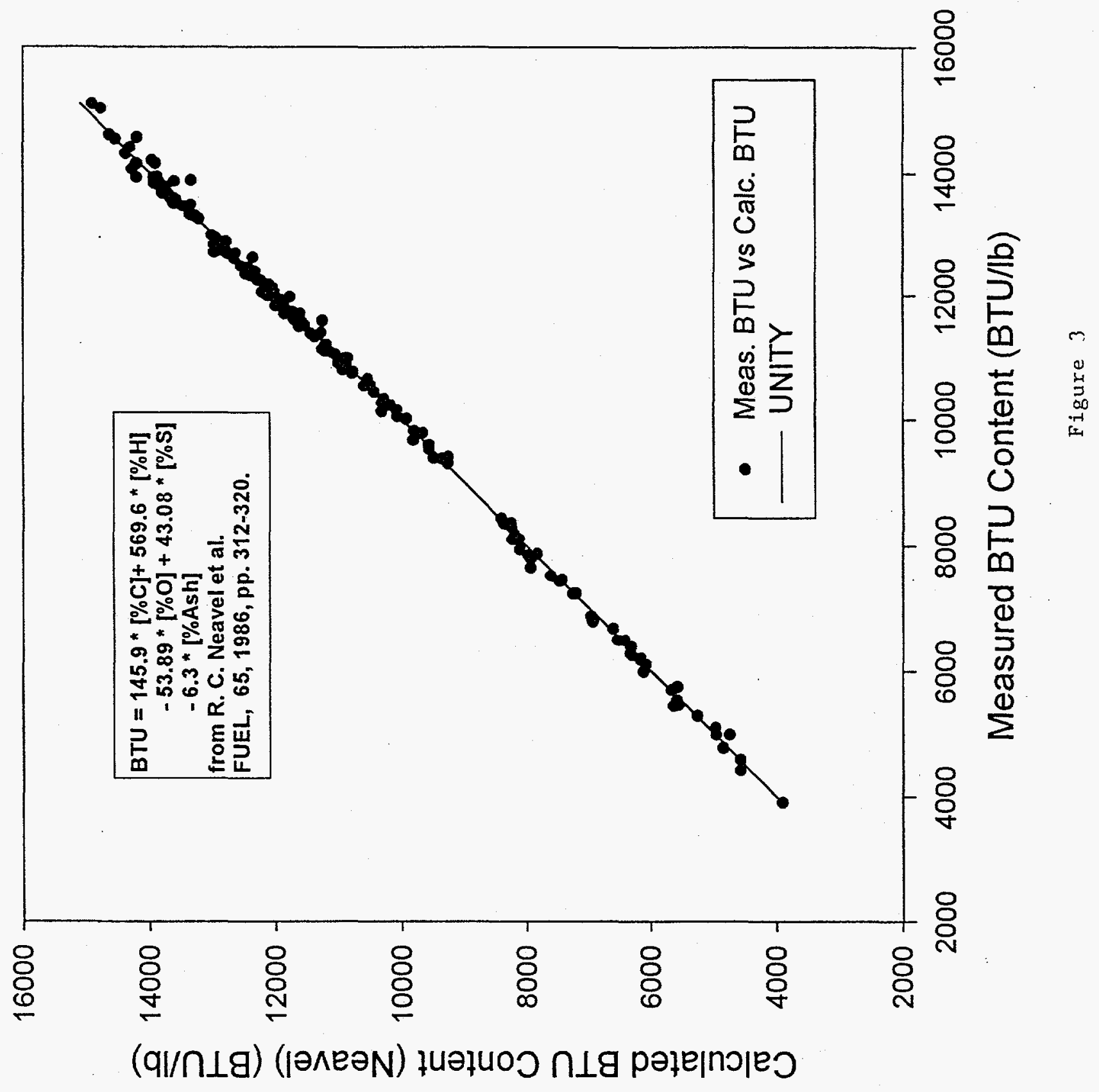

